\title{
Determinants of Tourists Arrivals in The East Coast Peninsular Malaysia: An Exploratory Factor Analysis
}

Hazrin Izwan Che Haron@shafiee, Juliana Arifin, Ahmad Shukri Yazid

To Link this Article: http://dx.doi.org/10.6007/IJARBSS/v11-i7/10162

DOI:10.6007/IJARBSS/v11-i7/10162

Received: 10 May 2021, Revised: 12 June 2021, Accepted: 22 June 2021

Published Online: 06 July 2021

In-Text Citation: (Haron@shafiee et al., 2021)

To Cite this Article: Haron@shafiee, H. I. C., Arifin, J., \& Yazid, A. S. (2021). Determinants of Tourists Arrivals in The East Coast Peninsular Malaysia: An Exploratory Factor Analysis. International Journal of Academic Research in Business and Social Sciences, 11(7), 241-256.

\section{Copyright: @ 2021 The Author(s)}

Published by Human Resource Management Academic Research Society (www.hrmars.com)

This article is published under the Creative Commons Attribution (CC BY 4.0) license. Anyone may reproduce, distribute, translate and create derivative works of this article (for both commercial and non-commercial purposes), subject to full attribution to the original publication and authors. The full terms of this license may be seen at: http://creativecommons.org/licences/by/4.0/legalcode

Vol. 11, No. 7, 2021, Pg. 241 - 256

Full Terms \& Conditions of access and use can be found at http://hrmars.com/index.php/pages/detail/publication-ethics 


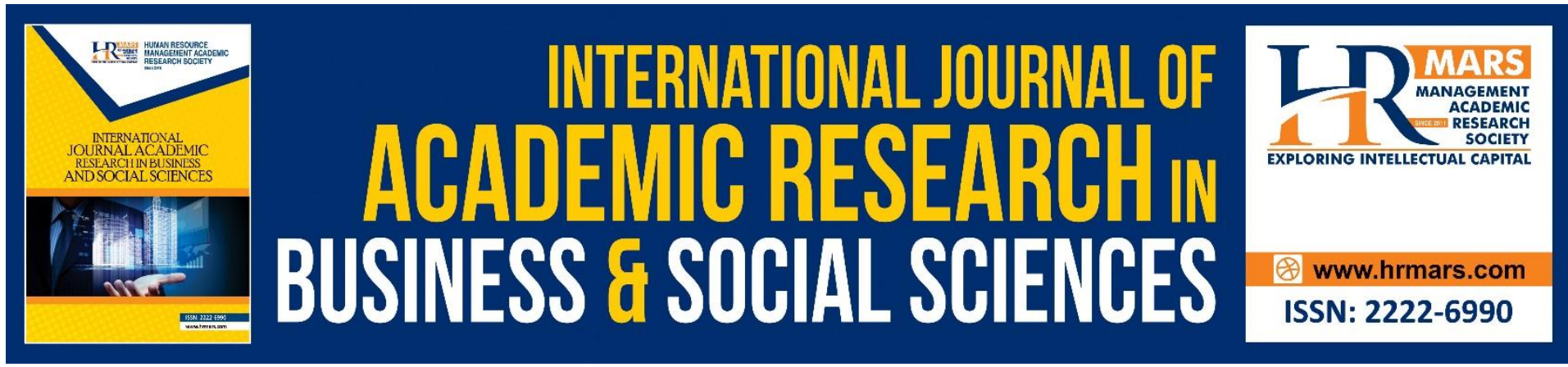

\title{
Determinants of Tourists Arrivals in The East Coast Peninsular Malaysia: An Exploratory Factor Analysis
}

\section{Hazrin Izwan Che Haron@shafiee1, Juliana Arifin², Ahmad Shukri Yazid ${ }^{3}$}

${ }^{1}$ PhD Student, Faculty of Business and Management Sciences, Universiti Sultan Zainal Abidin (Terengganu), Malaysia, ${ }^{2}$ Lecturer, Faculty of Business and Management Sciences, Universiti Sultan Zainal Abidin (Terengganu), Malaysia, ${ }^{3}$ Professor, Faculty of Business and Management Sciences, Universiti Sultan Zainal Abidin (Terengganu), Malaysia.

\begin{abstract}
The east coast peninsular Malaysia is richly endowed with beautiful ambiance of folk arts and has various cultures and unique art inherited for ages. However, number of domestic and international tourist that visit to Terengganu, Pahang and Kelantan is not encouraging where a percentage drop of tourist arrivals has been recorded. Hence, this study focuses on the determinant factors that attract tourists' arrivals in the East Coast Peninsular Malaysia and the objective is to investigate the relationship between determinant factors which are facilities and infrastructures, strategies, cultures and policies that influence the tourist arrivals to the east coast peninsular Malaysia. The instrument was pretested using questionnaires that have been adapted from several scholars. The questionnaires for the pilot study was organized into 6 sections and conducted towards hundred (100) respondents, which are tourists that travel and accommodate themselves in hotels at Kuala Terengganu. In contrast, the major discussion in this article is focusing on analysing data using exploratory factor analysis. The process started with the evaluation of data, factor extraction and retention method, selection of rotational method and labelling and naming the factor. An empirical verification of the validity and reliability of the survey questionnaire was developed. Exploratory Factor Analysis highlights the summarization of all 22 item-analysis output. The result from reliability test indicates an affirmative result where the Cronbach's alpha coefficient is 0.932 which highlights the quality and consistency of the questionnaire's items. Moreover, the sampling is proven adequate as shown in KMO and Bartlett test and the scree plot revealed 4 factors which are consistent with the number of variables in theoretical framework. The Rotated Component Matrix shows that all five factor components matrix items scored above 0.50 and there is no item deleted. These results proven that this study's instruments are valid for data collection process and able to be continued with the Confirmatory Factor Analysis.
\end{abstract}

Keywords: Tourism, Tourist destination, Sustainability, Tourism development, East Coast Peninsular Malaysia. 


\section{Introduction}

Terengganu, Kelantan and Pahang are states located in the eastern part of the peninsular Malaysia. These states share several things in common such as vast lands located on long wide sandy beaches and tourists' islands (Hassan, 2009). Pahang is considered as the successful and achieve high growth of tourism development with second largest supplier of hotel rooms in Malaysia (Hassan, 2009). On the contrary, Terengganu and Kelantan seemingly have low volume of hotel rooms which needs to be developed. Furthermore, Hassan (2009) claimed that Terengganu and Kelantan still in small ratio in tourism industry development.

Tourist arrivals at Merang jetty has been reported decreased and only few buses seen, carrying tourists at the jetty (Bernama, 2014). During two-hour observation, Bernama (2014) reported that the place was so quiet where the tourism activities are not busy and boasted as before. Tourism activities in Pulau Perhentian and Pulau Redang ceased following the monsoon season (Bernama, 2014). Furthermore, Jaafar (2012) also added that this situation also impact decrement on tourists visiting and camping at Kuala Terengganu. Pahang also has recorded decrement of Singaporean tourists' arrival in 2013 (Bernama, 2014) and correspondingly, Ching et al (2011) stated that the tourism player complained on tourist's declination especially the foreign tourists in state's coastal areas. Same scenario was experienced in Kelantan where number of foreign tourists' staying at hotel has dropped into 60,588 people in 2012 ( Sobihah et al., 2014).

Huibin et. al (2013); Salman and Hasim (2012); Idowu and Bello (2010); Guat (2013) have point out that safety and security, business stability, telecommunication, price sensitivity and marketing strategies have striking effect in attracting tourists to visit the destination. A research gap is developed to investigate, identify problem and explore potential that not been respond appropriately. Facilities and infrastructures, strategies, cultures and policies have been empirically observed and discovered as determinant factors that effect on tourists' arrival to the east coast peninsular Malaysia. Also, opportunities in research gap are explored by these factors that lead into advantages and disadvantages in tourism fields.

\section{Materials and Methods}

A total of 100 questionnaires were distributed in 16 hotels in the east coast of peninsular Malaysia. The questionnaires consist of six sections which are section $A$; general info, Section B; tourists' arrivals, section C; facilities and infrastructure, section D; strategies, section $\mathrm{E}$; cultures and section $\mathrm{F}$; policies.

The questionnaire was adopted from several scholars to meet the objectives for this study. The first part is the general info that is adopted from Khadaroo and Seetanah (2008) and collects the socio-demographic information referring to sex, age and nationality. Second, is the section about the tourists' arrivals (dependable variable) adopted from Akan et al (2008). Third, this is the part that talks about facilities and infrastructures (independent variable) adopted from Khadaroo and Seetanah (2008) that inquires on the quality of the accommodation, transportation services, recreational activities and service at tourist information. Fourth, the section that deals with strategies (independent variable) adopted from Mansor et al (2011). This section ascertains tourists' expectation towards the implemented tourism strategies, plan and promotion.

The next section elaborates about cultures (independent variable) and is adopted from Khadaroo and Seetanah (2008) and Mansor et al. (2011) that finds out on tourists' expectation towards local culture, local custom, performance, craft and tradition. Finally, the 
fifth section is about policies (independent variable) which is adopted from Anuar et al. (2012) which measures opinion and expectations towards good policy, current legislation, free trade policy and tourism governance bodies.

\section{Exploratory factor analysis}

The exploratory factor analysis (EFA) is obviously the most reliable method for construct and instrument validity. Thus, one of the methods to determining validity and data reduction is called exploratory factor analysis. EFA enables researcher to easily identify the presents of multicollinearity factors, assessing the construct validity and unidimensionality of constructs, development of theoretical constructs and proposed theories (Pett et al., 2003). Stages in conducting the EFA are illustrated as below (refer Figure 1):

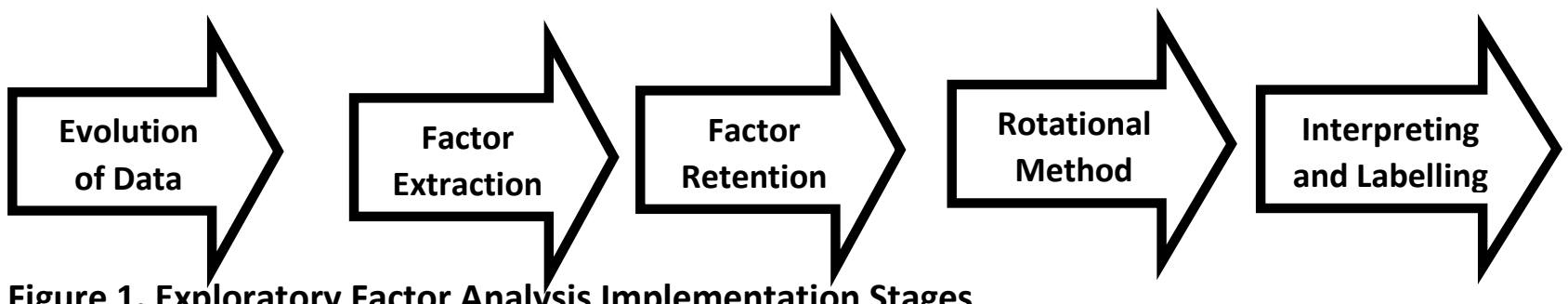

Figure 1. Exploratory Factor Analysis Implementation Stages

\section{A. Evaluation of data suitability}

Prior to proceeding with the final study, a pilot study was conducted with a set of 100 questionnaires to assess the reliability and validity of the items in the questionnaires. A simple rule in determining sample size is based on Roscoe (1975) that suggested a minimum number of 30 and less than 500. The sample size is according to table from Sekaran and Bougie (2016) that applies to any population of defined bounded size and there are no calculations required. Therefore, the population of the tourists' arrivals in 2012 for Terengganu was 7.9 million, Pahang is 7.7 million and for Kelantan is 10.3 million which constitute a total population of $25,940,000$. Thus, the total sample size required to be representative of the opinion is $\mathrm{N}=100,000$, so the total sample size for this population is 384 . However, in order to control for deficiencies from obtained responses, two more questionnaires have been added, thus making the total sample size of 386.

Table 1. Total Sample

\begin{tabular}{|l|l|l|l|l|l|}
\hline No & States & $\begin{array}{l}\text { Total } \\
\text { Population } \\
\text { ('000) }\end{array}$ & $\begin{array}{l}\text { Total } \\
\text { Percentage }\end{array}$ & $\begin{array}{l}\text { Total } \\
\text { Sample }\end{array}$ & $\begin{array}{l}\text { Total Sample For Each } \\
\text { state }\end{array}$ \\
\hline 1 & Terengganu & 7,939 & $31 \%$ & & 120 \\
2 & Pahang & 7,689 & $29 \%$ & 386 & 112 \\
3 & Kelantan & 10,312 & $40 \%$ & 384 \\
& Total & 25,940 & $100 \%$ & & 386 \\
\hline
\end{tabular}

\section{B. Correlation matrix}

It is important to remove any uncorrelated items as to ensure the suitability of the data. Henson and Roberts (2006) and Foziah et al. (2018) stated that the process could possibly be done by examining the relationship between highest and lowest correlation items 
in each construct through correlation matrix. Foziah et al. (2018) recommended that the perfect choice is by removing correlation item with correlation coefficients lower than 0.30 in the matrix.

\section{Reliability test}

A pre-test of the instrument was carried out to ascertain the reliability and consistency of the measurement scales which is the regular criteria that must be achieved through the validity and reliability of the constructs. George (2011) suggested that when the validity and reliability are properly addressed, and the measurement error, data input error as well as ambiguous response is reduced. The reliability analysis is aimed at measuring the items under each of the constructs. The most common measure of reliability is the Cronbach's Alpha. Usually, Cronbach's Alpha of 0.6 or higher for a component reflects that the measuring items under particular component provides a reliable measure of internal consistency (George, 2011).

\section{Kaiser Meyer Olkin (KMO) and the Bartlett's Test of Sphericity}

Burton and Mazerolle (2011) stated that KMO test is used to identify sample quality and data suitability which indicates the intensity of a particular item correlates with other items in the exploratory factor analysis correlation matrix. The KMO value achieved above 0.6 is indicated as an excellent fulfilment of the requirement, since it exceeds the recommended value (Bartlett, 1950) and value of less than 0.49 is unacceptable. KMO test less than 0.60 shows the presence of large partial correlations compared to the sum of correlations which prevent the production of distinct and reliable factors. Whereas Bartlett (1950) suggests that the Bartlett's test tells whether a chi-square output that must be significant or not as a small significant level $(p<0.05)$ is considered as a rejection of the null hypothesis, which indicates the presence of correlations between variables.

\section{E. Factor Extraction}

Factor extraction process uses various approaches and as per clarified by Thompson (2004), the list of approaches are: maximum likelihood, principal components analysis, canonical, unweighted least squares, principle axis factoring, image factoring, alpha factoring and generalized least squares. Nevertheless, prior researchers are more prefer on principal components analysis and principle axis factoring (Thompson, 2004). Principle component analysis is recommended when there is no previous theoretical basis or model exists and axis factoring is used in determining the underlying factors related to a set of items (Costello and Osborne, 2005). Primarily, Kaiser's criterion is widely applied where factors with eigenvalues greater that than one should be maintained (Fabrigar et al., 1999).

\section{F. Communalities}

In real data, item communalities that are 0.80 and larger are hardly to happen and normally, communalities ranged from 0.40 to 0.70 are categorized as low to moderate communalities (Cattell, 1966). Communality with less than 0.40 shows that the items construct would not associate to other items.

\section{G. Scree plot}

Scree plot is a line plot of the eigenvalues of factors or principal components in an analysis. This test is relevant by determine the existence of scree plot which represent the 
eigenvalues for breaks or discontinuities. Cattell (1966) stated that by indicating the sharp break in the curve, the number of retained factors can acquired.

\section{H. Selecting Rotational Method}

Rotational method simplified factor analysis where interpretation of output can be made easily by maximizing high item loadings and minimizing low item loadings. Oblique and orthogonal rotations are two usable methods and this study used Varimax rotation (part of orthogonal rotations) as it is the most common used in analysing the exploratory factor analysis (Cattell, 1966). Varimax rotation able to produce much simpler structure and factors can be explained from the opposition of few variables with positive loadings to few variables with negative loadings. Rotated Component Matrix helps analyse and interpret output which consists of rotated factor loading. Afterwards, each variable will state the weight for each factor and the correlation between the variables and the factor. Kaiser (1958) recommended that value range from 0.32 is poor. Meanwhile the range of 0.55 is good, 0.63 is very good and 0.71 is excellent (Kaiser, 1958). On the contrary, 0.80 and above is very difficult to discover in the real data. Hence, Kaiser (1958) recommended that the factor loading with value of 0.40 to 0.70 is considered an average in majority research.

\section{Naming the factor components (interpretation)}

Naming the factor components is the step of determining the variables that corresponded to a construct and also known as interpretation stage where it decides name for a brand new construct. Minimum of two variables items need to be loaded on one single factor for labelling and grouping a single construct that has meaningful interpretation.

\section{Results and Discussion}

\section{A. Descriptive analysis}

The demographic profile of the respondents in this study is as illustrated in Table 2 below. 
Table 2. Demographic Characteristics of Participants $(N N=100)$.

\begin{tabular}{|c|c|}
\hline Participant's characteristics & Frequency (\%) \\
\hline $\begin{array}{l}\text { Age distribution of respondents } \\
\text { Less than } 20 \text { years } \\
20 \text { to } 29 \text { years } \\
30 \text { to } 39 \text { years } \\
40 \text { to } 49 \text { years } \\
50 \text { years above }\end{array}$ & $\begin{array}{l}4(4 \%) \\
28(28 \%) \\
35(35 \%) \\
23(23 \%) \\
10(10 \%)\end{array}$ \\
\hline $\begin{array}{l}\text { Gender distribution of the respondents } \\
\text { Male } \\
\text { Female }\end{array}$ & $\begin{array}{l}50(50) \\
50(50)\end{array}$ \\
\hline $\begin{array}{l}\text { Profession distribution of the } \\
\text { respondents } \\
\text { Government } \\
\text { Private } \\
\text { Self employed } \\
\text { Others }\end{array}$ & $\begin{array}{l}15(15 \%) \\
33(33 \%) \\
24(24 \%) \\
28(28 \%)\end{array}$ \\
\hline $\begin{array}{l}\text { Tourists' nationality } \\
\text { Local tourists } \\
\text { Foreign tourists }\end{array}$ & $\begin{array}{l}50(50 \%) \\
50(50 \%)\end{array}$ \\
\hline $\begin{array}{l}\text { Tourists' arrival in East Coast Malaysia } \\
\text { Yes } \\
\text { No }\end{array}$ & $\begin{array}{l}37(37 \%) \\
63(63 \%)\end{array}$ \\
\hline \multicolumn{2}{|l|}{ (Cont.) } \\
\hline $\begin{array}{l}\text { Tourists' last visit to East Coast Malaysia } \\
2005 \\
2007 \\
2008 \\
2009 \\
2010 \\
2011 \\
2012 \\
2013 \\
2014 \\
2015 \\
\text { No answer }\end{array}$ & $\begin{array}{l}1(1 \%) \\
1(1 \%) \\
3(3 \%) \\
3(3 \%) \\
6(6 \%) \\
3(3 \%) \\
4(4 \%) \\
5(5 \%) \\
10(10 \%) \\
4(4 \%) \\
60(60 \%)\end{array}$ \\
\hline
\end{tabular}

\section{B. Correlation matrix}

The correlation matrix for tourist arrivals consists of 4 items, facilities and infrastructures variable consist of 6 items, strategies variable consists of 4 items, cultures variable consists of 5 items and policies variable consist of 4 items. Table 3 show the 
correlation matrix of tourist arrivals variable which comprises of 4 questions or items and no multicollinearity or singularity problem since there is no item scored greater than 0.85 . Similar to previous matrix, Table 4 shows the correlation matrix of facilities and infrastructures variable and no multicollinearity or singularity problem since there is no item scored greater than 0.85 .

Table 5 show the correlation matrix of strategies variable which comprises of 4 items and has indicated the absence of multicollinearity or singularity as there is no item scored greater than 0.85 . Table 6 show the correlation matrix of cultures variable which comprises of 5 items and all items are over 0.30 suggesting the matrix is factorable. Similar to previous matrix, Table 7 shows the correlation matrix of policies variable, also show no multicollinearity or singularity problem since there is no item scored greater than 0.85 . Subsequently, as per analysing result it can be concluded that no construct or variable should be removed from this study.

Table 3. Correlation Matrix - Tourist Arrivals

\begin{tabular}{|l|l|l|l|l|l|}
\hline \multicolumn{2}{|l|}{} & $\begin{array}{l}\text { Item } \\
1\end{array}$ & $\begin{array}{l}\text { Item } \\
2\end{array}$ & $\begin{array}{l}\text { Item } \\
3\end{array}$ & $\begin{array}{l}\text { Item } \\
4\end{array}$ \\
\hline \multirow{5}{*}{$\begin{array}{l}\text { Correlation } \\
1 \\
\text { Item } \\
\text { Item } \\
2 \\
\text { Item } \\
3 \\
\text { Item } \\
4\end{array}$} & 1.000 & .798 & .694 & .566 \\
& & 1.000 & .766 & .600 \\
\hline
\end{tabular}

Table 4. Correlation Matrix - Facilities and Infrastructures

\begin{tabular}{|l|l|l|l|l|l|l|l|}
\hline \multicolumn{2}{|c|}{} & Item 1 & Item 2 & Item 3 & Item 4 & Item 5 & Item 6 \\
\hline \multirow{3}{*}{ Correlation } & Item 1 & 1.000 & .740 & .359 & .578 & .590 & .640 \\
& Item 2 & & 1.000 & .448 & .579 & .720 & .713 \\
\hline \multirow{6}{*}{} & Item 3 & & & 1.000 & .342 & .481 & .462 \\
& Item 4 & & & & 1.000 & .635 & .665 \\
& Item 5 & & & & & 1.000 & .791 \\
& Item 6 & & & & & & 1.000 \\
\hline
\end{tabular}

Table 5. Correlation Matrix - Strategies

\begin{tabular}{|l|l|l|l|l|l|}
\hline \multicolumn{1}{|l|}{} & $\begin{array}{l}\text { Item } \\
1\end{array}$ & $\begin{array}{l}\text { Item } \\
2\end{array}$ & $\begin{array}{l}\text { Item } \\
3\end{array}$ & $\begin{array}{l}\text { Item } \\
4\end{array}$ \\
\hline & $\begin{array}{l}\text { Item } \\
1 \\
\text { Item } \\
\text { Correlation }\end{array}$ & 1.000 & .412 & .588 & .590 \\
& $\begin{array}{l}\text { Item } \\
\text { Item } \\
\text { Item } \\
4\end{array}$ & 1.000 & .549 & .507 \\
& & 1.000 & .751 \\
\hline
\end{tabular}


Table 6. Correlation Matrix - Cultures

\begin{tabular}{|l|l|l|l|l|l|l|}
\hline \multicolumn{2}{|c|}{} & Item 1 & Item 2 & Item 3 & Item 4 & Item 5 \\
\hline \multirow{4}{*}{ Correlation } & Item 1 & 1.000 & .646 & .648 & .651 & .670 \\
& Item 2 & & 1.000 & .721 & .662 & .607 \\
& Item 3 & & & 1.000 & .781 & .648 \\
& Item 4 & & & & 1.000 & .662 \\
& Item 5 & & & & & 1.000 \\
\hline
\end{tabular}

Table 7. Correlation Matrix - Policies

\begin{tabular}{|c|c|c|c|c|c|}
\hline & & $\begin{array}{l}\text { Item } \\
1\end{array}$ & $\begin{array}{l}\text { Item } \\
2\end{array}$ & $\begin{array}{l}\text { Item } \\
3\end{array}$ & $\begin{array}{l}\text { Item } \\
4\end{array}$ \\
\hline Correlation & $\begin{array}{l}\text { Item } \\
1 \\
\text { Item } \\
2 \\
\text { Item } \\
3 \\
\text { Item } \\
4\end{array}$ & 1.000 & $\begin{array}{l}.560 \\
1.000\end{array}$ & $\begin{array}{l}.493 \\
.408 \\
1.000\end{array}$ & $\begin{array}{l}.400 \\
.617 \\
.345 \\
1.000\end{array}$ \\
\hline
\end{tabular}

\section{Reliability test}

Table 8 below summarized the item-analysis output from SPSS for the multi-item scale of determinants factors that influence tourist' arrival to the east coast Peninsular Malaysia. The scale statistics highlights the summarization of 22 items incorporating the scale. From the output, it can be notices that the means is equal to 150.379; the Standard Deviation is equal to 28.377 whereas the Variance for the Scale Statistics is 805.299. From the table, it can be highlighted that the Cronbach's alpha coefficient is 0.932 which point out the measurement of internal consistency of a set of 22 items. On the other hand, Standardized Item Alpha is 0.944 which refers to Cronbach's alpha coefficient of internal consistency when all scale items have been standardized. 
Table 8. Item-Analysis from SPSS Output

\begin{tabular}{|c|c|c|c|c|c|c|}
\hline & & & $\mathrm{N}$ & Mean & Variance & $\begin{array}{l}\text { Std. } \\
\text { Deviation }\end{array}$ \\
\hline Statistics for Scale & & & 22 & 150.3792 & 805.299 & 28.377 \\
\hline & Mean & Minimum & Maximum & Range & Max/Min & Variance \\
\hline $\begin{array}{l}\text { Item means } \\
\text { Item Variances }\end{array}$ & $\begin{array}{l}6.835 \\
4.051 \\
\end{array}$ & $\begin{array}{l}5.577 \\
2.239 \\
\end{array}$ & $\begin{array}{l}7.468 \\
2.239\end{array}$ & $\begin{array}{l}1.891 \\
16.912 \\
\end{array}$ & $\begin{array}{l}1.339 \\
8.553 \\
\end{array}$ & $\begin{array}{l}0.263 \\
12\end{array}$ \\
\hline $\begin{array}{l}\text { Inter- } \\
\text { Item Correlations }\end{array}$ & 0.434 & 0.073 & 0.798 & 0.725 & 10.898 & 0.018 \\
\hline Cronbach's alpha & fficien & & $\begin{array}{l}\text { Alpha } \\
0.932\end{array}$ & & $\begin{array}{l}\text { Standardi } \\
\text { Alpha } \\
0.944\end{array}$ & Item \\
\hline
\end{tabular}

\section{Kaiser Meyer Olkin (KMO) and the Bartlett's Test of Sphericity}

Table 9 highlights a value of 0.938 , indicates that the sampling is adequate and acceptable thus explained that the sample is strong enough to proceed with the exploratory factor analysis. Bartlett's test of Sphericity (Cattell, 1966) tells whether a chi-square output that must be significant or not as a small significant level $(p<0.05)$ is considered as a rejection of the null hypothesis, which indicates the presence of correlations between variables. Therefore, it can be concluded that the correlation matrix is not an identity matrix (Fabrigar, 1999). As illustrated in Table 10, the significant level of Bartlett's Test of Sphericity is highly significant 0.000 (sig. $p<0.05$ ). As a conclusion, this data sample in this study is acceptable for conducting Exploratory Factor Analysis.

Table 9. Result of Kaiser Meyer Olkin (KMO) and Bartlett's Test

\begin{tabular}{|l|l|}
\hline Kaiser-Meyer-Olkin Measure of Sampling Adequacy & 0.938 \\
\hline Bartlett's Test of Sphericity & $\begin{array}{c}\text { Sig. level } \\
0\end{array}$ \\
\hline
\end{tabular}

\section{E. Factor Extraction}

The eigenvalue can be distinguished by observing Total Variance Explained Table (see Table 10) which consists of the eigenvalues associated with each linear component (factor) before extraction, after extraction and after rotation. The Extraction Sums of Squared Loadings column shows the factors that met the cut-off value which is identical to the Initial Eigenvalues (factors that have eigenvalues less than 1 are not shown), As previously explained, the number of factors that should be extracted can be determined by observing at factors that have eigenvalues greater than 1 and therefore, the totals of 4 factors have been extracted. 
Table 10 (a). Total Variance Explained

\begin{tabular}{|c|c|c|c|c|c|c|}
\hline \multirow{2}{*}{ Component } & \multicolumn{3}{|c|}{ Initial Eigenvalues } & \multicolumn{3}{|c|}{$\begin{array}{l}\text { Extraction Sums of Squared } \\
\text { Loadings }\end{array}$} \\
\hline & Total & $\begin{array}{l}\% \text { of } \\
\text { Variance }\end{array}$ & $\begin{array}{l}\text { Cumulative } \\
\%\end{array}$ & Total & $\begin{array}{lr}\% & \text { of } \\
\text { Variance }\end{array}$ & $\begin{array}{l}\text { Cumulative } \\
\%\end{array}$ \\
\hline 1 & 10.304 & 46.836 & 46.836 & 10.304 & 46.836 & 46.836 \\
\hline 2 & 1.949 & 8.857 & 55.693 & 1.949 & 8.857 & 55.693 \\
\hline 3 & 1.397 & 6.352 & 62.045 & 1.397 & 6.352 & 62.045 \\
\hline 4 & 1.278 & 5.807 & 67.852 & 1.278 & 5.807 & 67.852 \\
\hline 5 & .991 & 4.503 & 72.355 & & & \\
\hline 6 & .665 & 3.021 & 75.377 & & & \\
\hline 7 & .590 & 2.680 & 78.057 & & & \\
\hline 8 & .559 & 2.541 & 80.598 & & & \\
\hline 9 & .552 & 2.511 & 83.108 & & & \\
\hline 10 & .451 & 2.048 & 85.157 & & & \\
\hline \multicolumn{7}{|l|}{ (Cont.) } \\
\hline 11 & .425 & 1.930 & 87.087 & & & \\
\hline 12 & .364 & 1.653 & 88.740 & & & \\
\hline 13 & .349 & 1.588 & 90.328 & & & \\
\hline 14 & .321 & 1.460 & 91.787 & & & \\
\hline 15 & .308 & 1.402 & 93.189 & & & \\
\hline 16 & .284 & 1.292 & 94.481 & & & \\
\hline 17 & .267 & 1.213 & 95.694 & & & \\
\hline 18 & .252 & 1.146 & 96.840 & & & \\
\hline 19 & .196 & .889 & 97.729 & & & \\
\hline 20 & .187 & .849 & 98.577 & & & \\
\hline 21 & .167 & .757 & 99.334 & & & \\
\hline 22 & .146 & .666 & 100.000 & & & \\
\hline
\end{tabular}

\section{F. Communalities}

Based on Kaiser Criterion, the totals of 4 factors have been extracted (refer Table 11 below). However, analysis on communalities items should be made in order to re-evaluate whether the number of factors to retain can be accepted. Kaiser criterion is acceptable when the average communality is greater than 0.60 ( 2 nd condition). In this case the second condition is met in which the average communalities equal to 0.678 (14.9275/22). As a conclusion, the decision to use Kaiser Criterion with principal components analysis should be retained thus, 7 factors may be accepted.

Table 11. Communalities

\begin{tabular}{|l|l|l|l|l|l|l|l|l|l|}
\hline Items & Ext. & Items & Ext. & Items & Ext. & Items & Ext. & Items & Ext. \\
\hline B1 & .773 & C2 & .739 & D1 & .508 & E2 & .737 & F2 & .750 \\
B2 & .820 & C3 & .360 & D2 & .472 & E3 & .788 & F4 & .693 \\
B3 & .778 & C4 & .574 & D3 & .658 & E4 & .772 & Total & $14.9275 / 22$ \\
B4 & .622 & C5 & .732 & D4 & .633 & E5 & .693 & AVE & 0.678 \\
C1 & .661 & C6 & .763 & E1 & .710 & F1 & .692 & & \\
\hline
\end{tabular}




\section{G. Scree plot}

Scree test is applicable by observing and analysing a scree plot which represent the eigenvalues for breaks or discontinuities. The scree plot shows four factors should be retained as a stable and clear bend curve is reached four factors. Therefore, there is the need to reset the value of the eigenvalue and insert a fix number of factors to four factors instead the previous value of eigenvalue greater than 1.

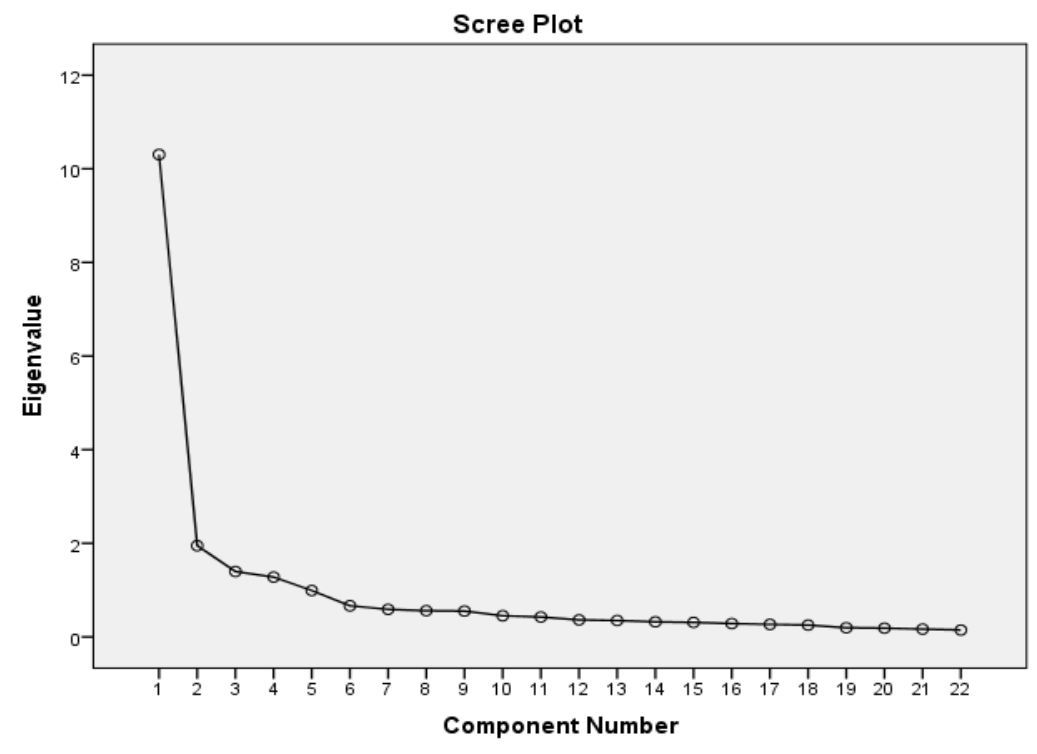

Figure 1. Plot of the First 22 Eigenvalues from the Analysis

\section{H. Selecting Rotational Method}

A Varimax rotation study is the most method used in analyzing the exploratory factor analysis. This method produces less complicated structure where variables interpret factors with positive and negative loadings (Cattell, 1966). By examining the Rotated Component Matrix, the interpretation of the output can be made. It consists factor loading of each variable, also the correlation between the variables and the factor and how the variables are weighted. Kaiser (1958) recommended that value range from 0.32 is poor. Meanwhile the range of 0.55 is good, 0.63 is very good and 0.71 is excellent (Kaiser, 1958).

\section{Naming the factor components (interpretation)}

Table 12 below shows that five factor components were identified and consistent with the variables construct which already discussed in a theoretical framework. All component matrix items scored above 0.50 and this allows the confirmatory analysis can be carry out using these five factor components in the next phase. Thus, Component 1 can be identified as tourist arrivals, Component 2 can be represented as facilities and infrastructures, Component 3 represent strategies, Component 4 as cultures and Component 5 as policies. 
Table 12. Rotated Component Matrix

\begin{tabular}{|c|c|c|c|c|c|}
\hline \multirow{2}{*}{ Component Matrix } & \multicolumn{5}{|c|}{ Component } \\
\hline & 1 & 2 & 3 & 4 & 5 \\
\hline $\begin{array}{l}\text { I am pleased to visit East Coast Peninsular Malaysia } \\
\text { again. }\end{array}$ & 0.884 & & & & \\
\hline The visit to this place exceeded my expectations & 0.916 & & & & \\
\hline $\begin{array}{l}\text { I will speak highly of this place to my friends and } \\
\text { colleagues }\end{array}$ & 0.887 & & & & \\
\hline I will definitely be visiting again within the next 5 years & 0.787 & & & & \\
\hline $\begin{array}{l}\text { The quality of the accommodation (hotel, homestay } \\
\text { and apartment) is good }\end{array}$ & & 0.811 & & & \\
\hline $\begin{array}{l}\text { Organization of the local transportation services is } \\
\text { good }\end{array}$ & & 0.874 & & & \\
\hline Great possibilities of night life, entertainment & & 0.602 & & & \\
\hline Great possibilities of shopping venue & & 0.786 & & & \\
\hline The places have availability of recreational activities. & & 0.877 & & & \\
\hline Service at Tourist Information Center given is good & & 0.89 & & & \\
\hline During the trip, I expect to find some unique activities & & & 0.784 & & \\
\hline $\begin{array}{l}\text { Promotional material advertising of the East Coast } \\
\text { Peninsular Malaysia meets my expectation }\end{array}$ & & & 0.733 & & \\
\hline I am here because of the great tourism event & & & 0.889 & & \\
\hline $\begin{array}{l}\text { Tourism strategies are well prepared for specific } \\
\text { destinations }\end{array}$ & & & 0.877 & & \\
\hline \multicolumn{6}{|l|}{ (Cont.) } \\
\hline $\begin{array}{l}\text { During the trip, my expectations about local culture } \\
\text { are met }\end{array}$ & & & & 0.841 & \\
\hline $\begin{array}{l}\text { During the trip, my expectations about Malay crafts } \\
\text { such as Batik making are met }\end{array}$ & & & & 0.847 & \\
\hline $\begin{array}{l}\text { East Coast Peninsular Malaysia offer great cultural } \\
\text { activities }\end{array}$ & & & & 0.889 & \\
\hline $\begin{array}{l}\text { The culture in East Coast Peninsular Malaysia is } \\
\text { unique }\end{array}$ & & & & 0.878 & \\
\hline $\begin{array}{l}\text { I would like to learn more about the local cultures and } \\
\text { traditions }\end{array}$ & & & & 0.834 & \\
\hline $\begin{array}{l}\text { In my opinion, a good policy implementation } \\
\text { contributes to sustainable tourism }\end{array}$ & & & & & 0.792 \\
\hline $\begin{array}{l}\text { The current legislation meets the needs of sustainable } \\
\text { tourism }\end{array}$ & & & & & 0.846 \\
\hline $\begin{array}{l}\text { Duty free zone can attract tourist to come to East } \\
\text { Coast Peninsular Malaysia }\end{array}$ & & & & & 0.703 \\
\hline $\begin{array}{l}\text { Governance of government agencies related to } \\
\text { tourism is effective }\end{array}$ & & & & & 0.762 \\
\hline
\end{tabular}




\section{Conclusion}

Exploratory factor analysis was demonstrated in this paper to study the determinants factors that influencing tourists' arrivals to east coast peninsular Malaysia. The data set has been tested and was found appropriate for factor analysis. The data has achieved its normality (whereas the KMO and Bartlett test shows that the sampling is adequate) and appropriate for factor analysis. Varimax rotational method has been chosen to reconfirm the number of retaining factor and all items factor loading are above 0.50 . Five which are; tourist arrivals, facilities and infrastructures, strategies, cultures and policies components have been identify as a valid construct for next analysis.

\section{Future Scope}

This paper focuses on reporting the method and study findings in EFA. Possible but not necessary EFA is a step-by-step process which is possible but not necessary some researchers, plus recommended for future researchers. It is endorsed by many scientific researchers that they distinguished objects by measuring an abundance of variables. Nevertheless, some large of variables in studies are complicated that might measure different aspects of a same underlying variable. Hence, conducting EFA will contribute advantageous specially to connect variables together under more general underlying variables. In addition, conducting EFA is useful for output using in future analysis.r 


\section{References}

Hassan, H. (2009). Ten Years After Asian Financial Crisis 1998: Tourism Growth in Malaysia. Integration \& Dissemination, 4.

Jaafar, M. (2012). Entrepreneurial marketing and accommodation businesses in East Peninsular Malaysia. Tourism and Hospitality Research, 12(2), 89-100.

Bernama. (2014). Peniaga dakwa hasil jualan merosot, Sinar Harian. Retrieved from https://www.sinarharian.com.my/edisi/terengganu/peniaga-dakwa-hasil-jualanmerosot

Bernama. (2014). Pahang optimis tarik pelancong Singapura tahun ini. Sinar Harian. Retrieved from https://www.sinarharian.com.my/politik/pahang-optimis-tarik-pelancongsingapura-tahun-ini-1.254198

Mutia Sobihah, A. H., Azman, N., Ali, M., Mahadzirah, M., \& Zulqurnain, W. I. (2014). Relationship between e-commerce service quality, satisfaction, trust, and customer loyalty in the hotel industry in the east coast of peninsular Malaysia.

Huibin, X., Marzuki, A., \& Razak, A. A. (2013). Conceptualizing a sustainable development model for cultural heritage tourism in Asia. Theoretical and empirical researches in urban management, 8(1), 51-66.

Salman, A., \& Hasim, M. S. (2012). Factors and competitiveness of Malaysia as a tourist destination: A study of outbound Middle East tourists. Asian Social Science, 8(12), 48.

Idowu, K. O., \& Bello, A. K. (2010). What are the factors determining tourists destinations in Africa?. Pakistan Journal of Social Sciences, 4(4), 301-303.

Guat, C. L. (2013). Factors Influencing the Intentions of Singaporean Tourists to Revisit Malaysia. European Journal of Tourism, 1(2), 35-43.

Khadaroo, J., \& Seetanah, B. (2008). The role of transport infrastructure in international tourism development: A gravity model approach. Tourism management, 29(5), 831840.

Akan, Y., Arslan, I., \& Işık, U. C. (2008). The Impact of Tourism on Economic Growth: The Case of Turkey. Journal of tourism, 9(2).

Mansor, N., Ahmad, W. A. W., \& Mat, A. C. (2011). Tourism Challenges among the SMEs in State of Terengganu. International Journal of Business and Social Science, 2(1).

Anuar, A. N. A., Ahmed, H., Jusoh, H., \& Hussain, M. Y. (2012). Understanding the role of stakeholder in the formation of tourist friendly destination concept. J. Mgmt. \& Sustainability, 2, 69.

Pett, M. A., Lackey, N. R., \& Sullivan, J. J. (2003). Making sense of factor analysis: The use of factor analysis for instrument development in health care research. sage.

Roscoe, J. T. (1975). Fundamental research statistics for the behavioral sciences [by] John T. Roscoe.

Sekaran, U., \& Bougie, R. (2016). Research methods for business: A skill building approach. John Wiley \& Sons.

Henson, R. K., \& Roberts, J. K. (2006). Use of exploratory factor analysis in published research: Common errors and some comment on improved practice. Educational and Psychological measurement, 66(3), 393-416.

Foziah, N. H. M., Ghazali, P. L., Mamat, M., Salleh, F., Guci, D. A., Jaaffar, S. A. S., ... \& Yazid, A. S. (2018). Analysis of Private Sector Retiree's Decision towards EPF Retirement Benefit of Annuity-Based Option. International Journal of Engineering and Technology (UAE), 7(3.28), 185-88. 
George, D. (2011). SPSS for windows step by step: A simple study guide and reference, 17.0 update, 10/e. Pearson Education India.

Burton, L. J., \& Mazerolle, S. M. (2011). Survey instrument validity part I: Principles of survey instrument development and validation in athletic training education research. Athletic Training Education Journal, 6(1), 27-35.

Bartlett, M. S. (1950). Tests of significance in factor analysis. British Journal of statistical psychology, 3(2), 77-85.

Thompson, B. (2004). Exploratory and confirmatory factor analysis: Understanding concepts and applications. Washington, DC, 10694.

Costello, A. B., \& Osborne, J. (2005). Best practices in exploratory factor analysis: Four recommendations for getting the most from your analysis. Practical assessment, research, and evaluation, 10(1), 7.

Fabrigar, L. R., Wegener, D. T., MacCallum, R. C., \& Strahan, E. J. (1999). Evaluating the use of exploratory factor analysis in psychological research. Psychological methods, 4(3), 272.

Cattell, R. B. (1966). The scree test for the number of factors. Multivariate behavioral research, 1(2), 245-276.

Kaiser, H. F. (1958). The varimax criterion for analytic rotation in factor analysis. Psychometrika, 23(3), 187-200. 